\title{
Küresel Kuruluşların Kriz Yönetimi ve İletişimi Süreçlerine Yönelik Bir Değerlendirme: Facebook \& Cambridge Analytica Veri Skandalının Retoriksel Arena Kuramı Bağlamında İncelenmesi ${ }^{1}$
}

\section{Onurcan Güden}

\author{
Araştırma Görevlisi \\ Galatasaray Üniversitesi \\ iletişim fakültesi, reklamcııık ve tanıtım anabilim dalı \\ onurcangueden@gmail.com \\ Orcid: 0000-0001-6418-2585
}

\begin{abstract}
An Evaluation of Crisis Management and Communication Processes of Global Organizations: A Case Study of Facebook \& Cambridge Analytica Data Breach Scandal in the Context of Rhetorical Arena Theory
\end{abstract}

\begin{abstract}
Crises create a great degree of uncertainty and threaten the reputation and the relations of the organization as well as its stakeholders, therefore, they represent a turning point for organizations. Thus, organizations that wish to continue existing are involved in the crisis management process which includes efforts to eliminate uncertainty and threats against their existence. The aim of this article is to evaluate the process of crisis management and communication within an interactive framework. To this end, from the multi-vocal approach of Frandsen and Johansen, the crisis management process of Facebook \& Cambridge Analytica data breach scandal has been evaluated as a case study. The strategies that Facebook and Cambridge Analytica resorted to during the phase of reacting and responding to the crisis have been examined and the different results of their crisis management processes have been put forward. Furthermore, at the macro level, the rhetorical arena has been reviewed and different actors who were involved in the

1 Galatasaray Üniversitesi Stratejik Iletişim Yönetimi (GSÜStrat) Konferansları 1: 21. Yüzyılın Krizleri: Yönetim, Iletişim ve Etik, 19 Aralık 2018.
\end{abstract}

DOI:10.16878/gsuilet.656553 
process of crisis communication have been identified in order to assess their impact on the process. Lastly, the disclosure of user data, which is at the core of the working models of these global companies, to third parties has been considered as an ethical issue. It has been concluded that if they do not take corrective action against this problem, they will potentially be vulnerable to different crises. theory.

Keywords: Crisis management, crisis communication, rhetorical arena

\begin{abstract}
Evaluation de gestion de crise et de processus de communication des entreprises mondiaux: étude de cas du scandale de violation des données de Facebook et de Cambridge Analytica dans le contexte de la théorie de lıarène rhétorique
\end{abstract}

\title{
Résumé
}

Les crises créent une grande incertitude et menace pour la réputation et les relations des l'entreprises ainsi que de ses parties prenantes. Elles représentent donc un tournant pour eux. Ainsi, les entreprises qui souhaitent de continuer à exister participent au processus de gestion de crise qui sert à éliminer les incertitudes et les menaces contre leur existence. Le but de cet article est d'évaluer le processus de gestion de crise et de communication dans un cadre interactif. Dans ce contexte, à partir de liapproche multi-vocale de Frandsen et Johansen, le processus de gestion de crise de violation de données de Facebook \& Cambridge Analytica a été évalué en tant quiétude de cas. Les stratégies auxquelles Facebook et Cambridge Analytica ont eu recours pendant la phase de réaction à la crise et leurs processus de gestion de crise ont été examinés pour mettre en scène les différents résultats de leur gestion de ce processus. En outre, la théorie de lıarène rhétorique a été évaluée au niveau macro et différents acteurs de ce processus de communication de crise ont été identifiés afin diévaluer leur impact. Enfin, pour ces entreprises mondiaux mentionnés ci-dessus, la divulgation des données des utilisateurs à des tiers a été considérée comme une question diéthique. II a été conclu que s'ils ne prenaient pas de mesures correctives contre ce problème, ils seraient potentiellement vulnérables à des différentes crises.

Mots-clés: Gestion de crise, communication de crise, la théorie de lıarène rhétorique. 


\section{Öz}

Kuruluşlar için dönüm noktası anlamına gelen krizler, büyük ölçüde belirsizlik yaratarak kuruluşun itibarını ve paydaşlarıyla ilişkilerini tehdit etmektedir. Varlıklarını sürdürmeye devam etmek isteyen kuruluşlar, belirsizliği ve tehditleri ortadan kaldırmaya yönelik çabaları içeren kriz yönetimi sürecine girerler. Bu çalışmanın amacı, farkı kaynakların gönderdiği mesajlarla çok sesli ortamda şekillenen kriz yönetimi sürecini, etkileşimsel çerçevede değerlendirmektir. Bu doğrultuda Frandsen ve Johansen'in çok sesli yaklaşımından hareketle, Facebook \& Cambridge Analytica veri skandalının kriz yönetim süreci vaka analizi olarak değerlendirilmiştir. Veri skandalına yönelik retorik arena makro düzeyde gözden geçirilerek krizin iletişim sürecine katılan aktörler saptanmış, sürece etkileri belirlenmiştir. Facebook ve Cambridge Analytica'nın başvurdukları kriz tepki stratejileri incelenerek kriz yönetim sürecinin iki kuruluş için getirdiği farklı sonuçlar ortaya konmuştur. Son olarak söz konusu küresel kuruluşların çalışma modellerinin özünde yer alan "kullanıı verilerinin dış kaynaklara açıklanması" etik bir sorun olarak görülmüş, bu sorunu düzeltme ve dönüşme yoluna gitmedikleri takdirde farklı potansiyel krizlere açık oldukları kanısına varılmıştır.

Anahtar kelimeler: Kriz yönetimi, kriz iletişimi, retoriksel arena kuramı. 


\section{Giriş}

Krizler yalnızca günümüze özgü değil, ancak gelişen yeni iletişim teknolojileri ve küreselleşme ile birlikte 21. yüzyılın krizleri her zamankinden daha fazla görünür hale gelmiş durumdadır. Günümüzde, küresel kuruluşların yaşadıkları krizler de küresel bir boyut kazanmakta, hedef kitleler ve paydaşlar da kurumun içine girdiği bu yüksek oranda belirsizlik ve tehdit içeren süreçten hızla haberdar olmaktadır. Kuruluşların karşı karşıya kaldıkları bu dönüm noktasında vereceği tepkiler, ya dönüşerek varlıklarını sürdürmeye devam etmelerini sağlayacak ya da yok olup gitmelerine neden olacaktır. Kuruluşlar, hedef kitlelerini, paydaşlarını ve genel olarak kamuyu krizle ilgili yeterli seviyede bilgilendirmediği ve normale dönülmesi için gerekli adımları atmadığı takdirde, karşılaşacağı tepkiler krizi derinleştirecek ve krizin yönetilmesini zorlaştıracaktır. Krizi iyi yönetemeyen kuruluşların güvenilirliği ve imajı sarsılacak, itibarı sorgulanmaya açık bir hale gelecektir.

17 Mart 2018'de The Guardian ve The Observer, The New York Times, Channel 4 News tarafından yayımlanan dosyalarla, Brexit Referandumu ve ABD Başkanlık Seçimleri'nde de kampanyalara destek sağlayan veri analiz ve siyasal danışmanlık şirketi Cambridge Analytica'nın, 50 milyondan fazla Facebook kullanıcısının (daha sonra 87 milyon olarak duyurulacak) kişisel verilerini uygunsuz ve izinsiz bir biçimde elde ederek kullandığı ortaya çıkmıştır. Bu çalışma, yayımlanan dosyalarla birlikte başlayan krizi yönetmeye çalışan şirketlerin kriz yönetim stratejilerini analiz etmeyi amaçlamaktadır. Veri krizinin tek bir sorumlusunun olmaması ve sürecin farklı kaynaklar tarafından gönderilen mesajlarla çok sesli bir ortamda şekillenmesi, söz konusu krizin etkileşimsel bir çerçevede değerlendirilmesini gerektirmektedir. Bu noktada, veri skandalına ilişkin bu kriz iletişimi analizinde Frandsen ve Johansen'in çok sesli yaklaşımı esas alınacaktır. Çok sesli yaklaşıma göre kriz iletişimi, kriz yönetiminin her aşamasında (kriz öncesi aşama, kriz aşaması ve kriz sonrası aşama) çeşitli aktörlerin kriz yönetimini etkilemek için iletişim çabaları ile ilgilidir. Çok sesli yaklaşım, aktörlerin destekleyerek, karşı çıkarak veya uzlaşarak krizi etkileme niyetleri üzerine odaklanmaktadır (Çınarlı, 2016, s.54). Veri skandalına ilişkin retorik arena makro düzeyde gözden geçirilerek, kriz iletişimi sürecindeki aktörler saptanacak, mikro modelin üç öğesi ile dört parametresi de göz önünde bulundurularak, kriz iletişimini tüm yönleriyle ele alabilmek adına Timothy Coombs'un (2012) kriz yönetiminin üç evresi olarak belirlediği; kriz öncesi, krize tepki ve kriz sonrası dönemler Facebook \& Cambridge Analytica özelinde analiz edilecektir.

\section{Kriz Kavramının Tanımlanması}

Kriz kelimesinin etimolojik kökeni eski Yunancada "krisis" (isim: karar) ve "krinein" (fiil: karar vermek) kelimelerinden gelmektedir ve tıbbi bir terim olarak, özellikle de bir hastalıkla ilgili dönüm noktasını ifade etmek üzere kullanılmıştır. Kriz kelimesinin kökeninde yer alan "dönüm noktası" anlamı bugün yalnızca hastalıklarla ilgili değil, aynı zamanda kurum ve kuruluşların karşı karşıya kaldıkları krizleri ifade ederken de kullanılmaktadır (Çınarlı, 2016, s.26). Türk Dil Kurumu (TDK) 
da tanımlamalarından birinde krizi, "bir ülkede ya da ülkeler arasında, toplumun veya bir kuruluşun yaşamında görülen güç dönem, bunalım, buhran." şeklinde açıklamaktadır (TDK, 2018).

Kriz yönetimine ilişkin erken literatürde Hermann (1963, s.64), krizlerin "kuruluşların değerlerini tehdit etmesi, tepki gösterilmesi için kısa zaman tanıması, kuruluşlar açısından beklenmedik ve öngörülemez olması" şeklinde üç özelliğe sahip olduğunu belirtmiştir. Bu özellikler bugün de kriz kavramının tanımlanmasına ilişkin geçerliliğini korumakla birlikte, küreselleşme ve neoliberal ekonomik düzen, kurum ve kuruluşların işleyiş biçimlerini değiştirmiş bununla beraber kriz kavramının tanımlamasına başka özelliklerin de eklenmesi gerekliliğini ortaya çıkarmıştır. Reid (2000, s.2), krizi, "bir örgütün pazardaki itibarına, onun paydaşlarıyla ilişkilerine ve tüm finansal durumlarına olumsuz etkisi olan her türlü durum" olarak nitelerken, Fearn-Banks (2011, s.2), krizi "potansiyel olumsuz çıktıları ile kuruluşu veya sektörü, aynı zamanda da onların hedef kitlelerini, ürünlerini, hizmetlerini veya iyi ismini etkileyen büyük bir olay" olarak değerlendirmiştir. Bu büyük olaylar aynı zamanda insanların nedenler ve isnatlar aradığı (Coombs ve Holladay, 2004, s.97), dinamik ve önceden tahmin edilemeyen (Seeger, 2006, s.234), her zaman doğrusal olmayan ve pek çok kez karmaşık bir süreçte ilerleyen (Roux-Dufort, 2007, s.109), zaman zaman kurbanlar da yaratan (Lukaszewski, 2013, s.22), yüksek düzeyde belirsizlik ortaya çıkaran ve aynı zamanda kuruluşun öncelikli amaçları için aynı anda hem tehditler hem de fırsatlar sunan, kendine özgü, beklenmedik, rutin olmayan olay ya da olaylardır (Ulmer ve diğerleri, 2011, s.7). Küreselleşme ve yeni medya teknolojilerindeki gelişmeler kriz kavramını ve buna bağlı olarak kriz yönetimi ve iletişimini de etkilemektedir. Geleneksel medyaya ek olarak, yeni medyanın çarpan etkisiyle bugün krizler daha görünür hale gelmiş vaziyettedir. Bu krizlerin etkileri küresel çapta hissedilmekte, kuruluşların paydaşları ve hedef kitleleri de kriz iletişimi sürecine müdahil olabilmektedir.

\section{Kriz Yönetimi ve Kriz İletişimi}

Halkla ilişkiler, en basit ifadeyle "bir örgüt ile o örgütün kitleleri arasındaki iletişim yönetimi" şeklinde tanımlanmaktadır (Grunig ve Hunt, 1984, s.6). Bir kriz meydana geldiğinde iletişimin yönetilmesi özellikle zorlaşır, etkisiz ve yetersiz bir kriz iletişimi hem kuruluşun hem de kuruluşun paydaşlarının karşılaşacağı zararı çoğaltabilir (Lerbinger, 2012, s.9). Halkla ilişkilerin bütünleyici bir parçası olan kriz yönetimi Coombs (2007) tarafından, "krizlerle mücadele etmek ve neden olduğu zararı önlemek ya da azaltmak için tasarlanan etmenler" olarak tanımlanmıştır (Coombs, 2007, s.5). Kriz yönetimi, "meydana gelen olumsuzluktan doğan riskin bir kısmını ve belirsizliği ortadan kaldırarak kuruluşun kendi kaderini daha fazla kontrol edebilmesine imkan veren stratejik bir planlama süreci"dir (Fearn-Banks, 2011, s.2). Kriz yönetiminin hayati bileşeni kriz iletişimi sürecidir. Bir krizin iletişim talebi "belirsizliği düzenlemek, krize tepki vermek, krizi çözümlemek ve ondan ders almaktır" (Çınarlı, 2016, s.39). Krizler bir vakumda gerçekleşmez, aksine krizler iç ve dış çevre faktörlerinden ve bu faktörlerin birbirleriyle etkileşiminden meydana gelmektedir. 
Kriz ortamının yarattığı belirsizlik, hedef kitleler ve paydaşlarda endişe ve heyecana sebep olmaktadır. Kuruluşlar, paydaşlarıyla gereken diyalogu sağlayamadıkları takdirde kriz anında söylenti, dedikodu ve spekülasyon oluşacaktır. Bu istikrarsız bilgi ve iletişim ortamının yönetilmesi, kriz iletişimi yönetimidir. Kriz iletişimi, belirli bir olayı açıklamayı, olası sonuçları tanımlamayı ve zararı azaltmak üzere etkilenen topluluklara dürüst, samimi, hızlı, doğru ve eksiksiz bir şekilde bilgiler sağlamayı amaçlamaktadır (Reynolds ve Seeger, 2005, s.46). Kriz sorumluluğunun kuruluşa ne düzeyde atfedildiğini etkilemek ve kitlelerin kriz ile ilgili algılarını şekillendirmek için kriz iletişimi kullanılmaktadır. Kriz iletişimi, yönetimin yalnızca söyledikleri değil, aynı zamanda yaptıklarıdır. Yönetim tarafından ortaya konan eylemler paydaşlarla sembolik bir iletişim kurulmasını sağlamaktadır (Coombs, 2018).

Kriz iletişimi aynı zamanda kuruluşların krizle karşı karşıya kaldıklarında geliştirdikleri savunma mekanizmalarıdır. Kuruluşlar bir krizle karşı karşıya kaldıklarında Kurumsal Savunca Söylemi'ne (Corporate Apologia) başvurabilmektedir. Bu kriz tepki stratejisi, kuruluşların kamusal personaları olduğundan hareket eder ve karaktere yapılan bu saldırı karşısında verilen bir tepki stratejisidir. Özrü de içerebilen kurumsal savunca; bir sosyal meşruluk krizine verilen tepkidir (Çınarlı, 2016, s.45-46). William Benoit tarafından geliştirilen bir diğer kriz iletişim stratejisi İmajın Yeniden İnşası (IRT: Image Restoration Theory) kuramıdır. Kurumsal Savunca Söylemi üzerine inşa edilen bu kuramda, itibarın savunulup korunması için iletişim kullanıı (Coombs, 2012, s.31-32). Başka bir kriz iletişim kuramı olan Durumsal Kriz Illetişimi Kuramı (SCCT: Situational Crisis Communication Theory) ise Coombs'un Bernard Weiner'ın bir sosyal-psikoloji kuramı olan Nedensellik Atfetme Kuramı'nı (Attribution Theory), kriz iletişimine retoriksel yaklaşımlarla birleştirilmesi sonucu ortaya çıkmıştır. İmajın Yeniden İnşası kuramının daha ileriye taşındığı stratejik bir yaklaşım olarak Durumsal Kriz İletişimi Kuramı, kriz iletişiminin biçimine ve içeriğine odaklanmaktadır. (Frandsen ve Johansen, 2012, s.427). Uygulama ve teoride kriz iletişiminin geleneksel olarak kitlesel bir iletişim paradigmasına dayandığına ve gönderici odaklı bakış açılarının hakim olduğuna işaret eden Falkheimer ve Heide (2009), kriz iletişimini etkileyen bir faktör olarak, toplumdaki çağdaş, kültürel ve etnik çeşitliliğe izleyici odaklı bir bakış açısıyla yaklaşılması gerektiğini vurgulamaktadır (Falkheimer ve Heide, 2009, s.56).

\section{Retoriksel Arena Kuramı}

Retoriksel Arena Kuramı temel olarak iki metafora dayanmaktadır; bunlardan ilki kriz meydana geldiğinde açıldığı varsayılan arena, diğeri ise bu arenada yankılanan seslerdir. Çoklu sesler arenada bir araya gelerek çarpışır, rekabet eder, işbirliği yapar ve müzakere ederler (Frandsen ve Johansen, 2018, s.94). Arena metaforu, krizde yer alan aktörlerin, sadece krizin kendisini nasıl yorumlayacakları konusunda değil, aynı zamanda krizi nasıl ele alacakları konusunda da birbirleriyle ettikleri mücadeleyi vurgulamaktadır. Ses metaforu ise, arenada birbirine karşı ve birlikte iletişim içerisinde olan birçok gönderici ve alıcı olduğunu vurgulamaktadır; burada önemli olan seslerin çokluğu ve karmaşıklığıdır (Frandsen ve Johansen, 
2018, s.94). İletişim sürecinin yalnızca gönderici ve alıcı ile sınırlı olmadığını belirten Frandsen ve Johansen, İmajın Yeniden İnşası Kuramı'nı mesajın göndericisini merkeze alan, Durumsal Kriz Iletişimi Kuramı'nı ise mesajın alıcısını ön planda tutan kriz iletişimi stratejileri olarak değerlendirmektedir (Frandsen ve Johansen, 2017, s.147). Kriz iletişiminin çok sesli sürecini ise şu şekilde tanımlamaktadırlar:

"Kriz iletişimi, bir kuruluş ve/veya bir ya da daha fazla paydaşı tarafından kriz olarak görülen bir olay, bir durum ya da olayların akışı öncesi, sırası ve sonrasında gelişen iletişim sürecinin karmaşık ve dinamik yapısından oluşmaktadır. Kriz iletişimi aynı zamanda da birbirleri ile alakası olan çeşitli aktörleri, bağlamları ve söylemleri de içermektedir" (Frandsen ve Johansen, 2012, s.431).

Retoriksel arena kuramı, kriz iletişimi sürecini makro ve mikro olmak üzere iki perspektif üzerinden değerlendirmektedir (Encyclopedia of Public Relations, 2013, s.798). Arenanın kendisi; bütün iletişim süreci olarak adlandırılan makro model, kriz sürecindeki kurumsal veya kurumsal olmayan (siyasi aktörler, medya, kriz uzmanları v.b.) tüm sesleri kapsamakta ve bu sesler arasındaki etkileşimi incelemektedir. Arenadaki aktörler birbirleri ile iletişim kurmakta, birbirlerine karşı görüşler dile getirmekte ve birbirleri hakkında konuşmaktadır. Retoriksel arenadaki bu iletişim süreci krizin ortaya çıkmasıyla birlikte farklı aktörlerin arenada varlık göstermeleri ile başlamaktadır ancak retoriksel arenanın varlığı yalnızca kriz sürecine bağı ı değildir, arena kriz öncesi dönemlerde de açılabilir ve kriz sonrasında da varlığı devam edebilir (Frandsen ve Johansen, 2012, s.432). Sosyo-retorik/ söylemsel olarak da adlandırılmakta olan mikro model ise kriz iletişimini içerik ve biçim açısından etkileyen dört parametre (bağlam, medya, tür, metin) ve üç öğeden (kriz iletişimi, mesajın kaynağı, mesajın alıcısı) oluşmaktadır (Encyclopedia of Public Relations, 2013, s.799). Illetişim sürecini yönlendiren üç öğe; kriz iletişimi, mesajın kaynağı ve mesajın alıcıları şeklindedir.

Kriz Iletişimi: Kriz öncesi, kriz anı ve kriz sonrası dönemleri ve karmaşık iletişim sürecini kapsamakta ve birbirleriyle ilişkili farklı aktörleri, söylemleri ve bağlamları içermektedir. Frandsen ve Johansen (2012), mesajın kaynağı ve alıcılarının birbirleri ve diğer aktörler ile birlikte anlam yaratma çabası olarak tanımladıkları iletişim faaliyetlerinin semiyotik boyutuna da değinmektedirler. Yani, sözel veya yazılı iletişimin yanı sıra resimler, eylemler ve davranışlar da iletişim sürecinde önemli bir yere sahiptir (Frandsen ve Johansen, 2012, s.434).

Mesajın kaynağı ve mesajın alıcıları ise: Retoriksel arenada iletişim sürecinde pek çok farklı aktör bulunmasından dolayı iletişim kuran bütün aktörleri (kurum, paydaşlar veya kurumsal olmayan diğer aktörler) kapsamaktadır. Bu aktörler; çıkar, anlamlandırma, strateji, sözel ve sözel olmayan iletişimsel davranış olmak üzere dört yetiye sahip olmalıdır (Frandsen ve Johansen, 2012, s.435). 
İletişim süreçlerine aracılık eden dört parametre şu şekildedir:

1. Bağlam: icçsel (psikolojik) ve dişsal (sosyolojik) bağlamlar iletişim süreçlerini belirlemektedir. İçsel bağlamlar, kriz türlerinin anlamlandırıması üzerinde etkiye sahip olan bilişsel şemalardan meydana gelmektedir. Sosyal/kültürel bağlam, örgütsel/kurumsal ve durumsal bağlamlar ise retoriksel arenanın doğasını belirleyen dışsal bağlamlardır (Frandsen ve Johansen, 2010, s.435-436).

2. Medya: Kriz mesajlarının taşıyıcılığını yapan medya; yazılı ve sözel dilin yanı sıra, yazılı basın, elektronik medya, online medya, sosyal medya, cep telefonları, kurumsal medya gibi teknolojik araçların kullanımını kapsamaktadır. Kriz iletişiminde seçilen medya türü arenadaki sesler tarafından alınan kriz mesajının nasıl, nerede, ne zaman ve neden alındığı üzerinde önemli bir etkiye sahiptir. Her medya çeşidinin farklı özelliklere sahip olması nedeniyle alıcı üzerinde yarattıkları etki de farklılık gösterebilmektedir (Frandsen ve Johansen, 2017, s.152).

3. Tür: Frandsen ve Johansen (2017, s.153) türü metinler topluluğu olarak adlandırmaktadır. Bu topluluk içerisindeki metinler aynı iletişimsel amaca ve kullanılan stratejiler bakımından ortak özelliklere sahiptir. Kriz iletişimi türleri kurumun içsel (toplantılar, e-postalar, makaleler v.b.) ve dısssal (basın açıklamaları, basın duyuruları, medya ve sosyal medyada yer alan içerikler v.b.) iletişimleri ile ilgilidir.

4. Metin: Sözel ve görsel semiyotik unsurların ve belirli durumlarda iletilen ve mesajın alıcıları tarafından yorumlanan retoriksel stratejilerin belirlenmesi ve uygulanması parametresidir. Metinler iletişim sürecinin bir ürünü olarak ortaya çıkmaktadır. İmajın Yeniden Inşası ve Durumsal Kriz Illetişimi kuramlarında kullanılan kriz tepki stratejileri bu parametrenin bileşenleridir (Çınarlı, 2016, s.56).

\section{Metodoloji}

Yukarıdaki literatüre dayanarak, bu çalışma küresel kuruluşların yaşadıkları krizlerde çok sayıda aktörün sürece dahil olmasıyla birlikte meydana gelen iletişimsel karmaşıkığı yansıtmayı ve bu kuruluşların kriz yönetimi ve iletişimi süreçlerini Facebook \& Cambridge Analytica veri skandalı özelinde bir vaka analizi olarak incelemeyi amaçlamaktadır. Retoriksel arena kuramının, krizlerin yalnızca krizi yaşayan kurumlarla sınırlı olmadığı ve çok sesli ve dinamik bir iletişim süreci olduğu önermelerinden hareketle, Facebook ve Cambridge Analytica'nın yaşadıkları krizde hangi aktörlerin devreye girdiği, krizin hangi mecralarda ne şekilde tartışıldığı, söz konusu şirketlerin başvurdukları kriz tepki stratejilerinin neler olduğu sorularına cevap aranacak, kriz süreci Coombs'un (2012) "kriz yönetiminin evreleri" temel alınarak analiz edilecektir. 


\section{Facebook \& Cambridge Analytica Veri Skandalı Vaka İncelemesi}

\section{Facebook}

2004'te Harvard Üniversitesi öğrencisi Mark Zuckerberg ve Dustin Moskovitz, Chris Hughes, Eduardo Saverin tarafından kurulan sosyal paylaşım ağı Facebook, öncelikle yalnızca Harvard öğrencilerinin erişimi için tasarlanmıştır. İki ay içerisinde Ivy Ligi'nde yer alan okulları da kapsayan ağa, bir yııın sonunda Amerika Birleşik Devletleri'ndeki bütün okullar katılmıştır. 2006'ya gelindiğinde Facebook rüzgarı kampüslerin dışına taşmış ve herkesin elektronik posta adresiyle ücretsiz katılabileceği bir platform haline gelerek, kullanıc sayısı 12 milyona ulaşmıştır.

Facebook misyonunu, "insanlara bir topluluk yaratabilme ve bir araya gelebilme gücü vermek" şeklinde açıklamaktadır. İnsanlar Facebook'u aileleri ve arkadaşlarıyla iletişimde kalmak, dünyada neler olup bittiğini keşfetmek ve kendilerince önemli olan şeyleri paylaşıp ifade etmek için kullanmaktadır. Facebook aralarında Instagram, WhatsApp, Oculus VR'ın da bulunduğu 50'den fazla yan kuruluşa sahiptir. Şirketin çalışan sayısı 27 bin 742'dir. 1 Ocak 2018 verilerine göre Facebook'un dünya çapında 2 milyar 72 milyon aylık aktif kullanıcısı bulunmaktadır (Omnicore Agency, 2018)

\section{Cambridge Analytica}

2013'te Alexander Nix tarafından kurulan Londra merkezli Cambridge Analytica (CA), misyonunu bireyleri neyin motive ettiğini anlamak ve istenilen yönde etkileşim kazanmak için "veriye dayalı davranışsal değişim sağlamak" şeklinde açıklayan bir veri analiz ve stratejik siyasi danışmanlık şirketidir (Cambridge Analytica, 2018). Şirketin kurulması için 15 milyon dolarlık mali kaynak, Amerika Birleşik Devletleri'nde Ted Cruz ve Donald Trump'ın kampanyalarını da destekleyen Robert Mercer tarafından sağlanmıştır. CA'nın bağlı bulunduğu ana şirket SCL Group (Strategic Communication Laboratories), 1990 yılında Nigel Oakes tarafından Behavioural Dynamics Institute (BDI) adıyla stratejik iletişim için bir araştırma tesisi olarak kurulmuştur. Oakes, kitle fikir ve davranışının nasıl belirlenip etkilenebileceği üzerine çalışmıştır.

SCL Group misyonunu, dünya çapında hükümetlere ve askeri örgütlere veri, analiz ve strateji sağlamak olarak açıklamakta, 25 yılı aşkın süredir 60'tan fazla ülkede davranış değişikliği programları uyguladıklarını ifade etmektedir (SCL Group, 2018). Cambridge Analytica, ABD'de 2015'teki ön seçimlerde Ted Cruz'a veri hizmeti sağlamış ve 2016 Başkanlık Seçimleri'nde Donald Trump'ın kampanyasına destek vermiştir. Yine 2016'da Birleşik Krallık'ın Avrupa Birliği Referandumu'nda "Leave EU" kampanyası için çalışmıştır. 


\section{Kriz Öncesi Evre}

Coombs'a $(2007$, s.5) göre bu aşamada erken uyarı sinyallerinin alınması, önleme ve hazırlık söz konusudur. Krizi yönetmenin en iyi yolu, kriz meydana gelmeden onu önlemektir (Çınarlı, 2016, s.37). Bu noktada krize neden olabilecek riskler saptanmalı, bu risklerin azaltılması hedeflenmeli ve potansiyel kriz ile ilgili paydaşları bilgilendirici mesajlar iletilmelidir (Coombs, 2012, s.26). Kriz öncesi dönemde Facebook'u değerlendirmeye başlamadan önce, Facebook'un 2006'dan sonra hızla büyümesini sağlayan iki dönüm noktasına değinmek yerinde olacaktır. Bunlardan ilki 2007 yılında uygulama geliştiricilere sınırsız erişim sunması ve ağ içinde etkileşimli uygulamalara yer vermesi, ikincisi ise 2009 yılında kullanıcıların içerikleri değerlendirebileceği "beğeni butonu"nu eklemesidir. Bu iki dönüm noktası aynı zamanda Facebook'un Cambridge Analytica ile yollarının kesişmesini sağlamış ve krize giden yolda ilk taşlar bu şekilde döşenmiştir.

2008'de Cambridge Üniversitesi Psikometri Merkezi'nden davranış bilimci iki doktora öğrencisi Michal Kosinski ve David Stillwell "Büyük Beşli" adlı davranış teorisi2 üzerine çalışmaktadır. Teoriyi test etmek ve sonuç elde etmek için de "MyPersonality" adlı bir Facebook uygulaması geliştirmiş ve böylece Facebook üzerinden gönüllü deneklerin bilgilerine erişim sağlamışlardır. Daha sonra eklenen Facebook'un "beğen" özelliği ile "büyük beşli teorisi" ilişkilendirilmiş ve yalnızca "beğeni butonu"nun kullanımından bir aboneyi 300 beğeniden biraz daha fazlasıyla kendinden bile daha iyi tanıyabileceklerini fark etmişlerdir. Kosinski ve Stillwell'in bu araştırmayı makale (Kosinski, Stillwell vd., 2013) olarak yayımlamalarının ardından Facebook, beğenilerin dışarıdan ölçümlenme erişimini engellemiştir.

Bir veri havuzuna ihtiyacı olan Cambridge Analytica da olaya bu zaman diliminde dahil olmuş ve Kosinski'nin yanında psikolojik modellemesine dair yeterince bilgi edinecek kadar bulunan Aleksandr Kogan ile anlaşmıştır. Kogan, 2014 yılında şirketi Global Science Research aracılığıyla Facebook üzerinde "This Is Your Digital Life" adlı bir kişilik testi başlatmıştır ve testi cevaplayanlara 1-2 dolar vererek, 270 bin kişiye ulaşmıştır. Ancak bu test yalnızca gönüllü deneklerle sınırlı kalmamış ve katılan 270 bin kişinin arkadaşlarının kişisel bilgilerine de erişilmiştir. Böylece Cambridge Analytica istediği veri havuzuna ulaşmıştır.

Frandsen ve Johansen (2012), kriz patlak verdiğinde retorik arenanın ortaya çıktığını, ancak aynı zamanda da krizden çok daha önce de ortaya çıkabileceğini ifade etmektedirler. Farklı aktörler bu arenada kriz ya da potansiyel kriz ile ilgili iletişimde bulunmak için varlık gösterirler (Frandsen ve Johansen, 2012, s.431-432). Aralık 2015'te The Guardian, ABD Senatörü Ted Cruzıun Facebook kullanıcılarının verilerini kullandığını ve konunun öznelerinin verilerinin şirketlere satılığından ve politikacıların kişisel bilgilerini aldıklarından habersiz olduklarını bildirmiştir (Davis,

2 Teori, bireylerin tüm davranışlarının kişiliklerindeki 5 temel unsur; "yeniliklere açıklık, mükemmeliyetçilik, sosyallik, uzlaşmacılık ve kırılganlık" üzerinden çözümlenebileceğini savunmaktadır. 
11 Aralık 2015). Bu noktada retorik arenanın krizden çok daha önce ortaya çıktığını söylemek mümkündür. Zuckerberg'in krize tepki evresinde (21 Mart 2018) Facebook üzerinden paylaştığı gönderisinden (Zuckerberg, 2018), öğrendiğimiz kadarıyla bu haberin üzerine 2015'te Kogan'ın uygulaması Facebook üzerinden kaldırımış, Kogan ve Cambridge Analytica'dan da uygunsuz şekilde elde edilen bu verileri silmeleri ve bunu resmi olarak belgelemeleri istenmiştir.

Kriz öncesi dönemde Facebook'un başı "filtre balonu", "sahte haber" gibi konularla da dertteydi. Öyle ki Facebook üzerinden yayılan "sahte haberlerin" seçim sonuçlarını etkilemiş olabileceği tartışılmaktadır. Ancak Zuckerberg, bunun "çılgınca bir fikir olduğunu" söylemiş ve "Facebook'un bir medya kuruluşu değil, insanların birbiriyle iletişim kurup bilgi paylaşabileceği bir açık teknoloji platformu" olduğunu ifade etmiştir (Sullivan, 8 Eylül 2017). Aynı dönemde, Facebook'un algoritma yapısının demokrasiyi baltalayan bir etkisi olduğu akademik çevrede sıklıkla konuşulmaktaydı (Binark, 2017; Bucher, 2017; Kim, 2016). Ayrıca daha fazla kullanıcıya ulaşmak, hızla büyümek ve bir işletme olduğu için temel olarak "para kazanmak" isteyen Facebook'un, "ürün bedavaysa ası ürün kullanıcıdır" sözünü doğrularcasına, kullanıcıları uygulama geliştiricilere ve reklam verenlere sattığı da biliniyordu (Madrigal, 2018; Porter, 2018; Stone, 2010, Tüfekçi, 2017). Bu noktada Facebook'un yaşadığı krizi, Cutlip, Broom ve Center'ın (1994), kriz süreci üzerine yoğunlaşan kriz sınıflandırmasında "gelişen kriz" kategorisine denk düştüğünü söyleyebiliriz. Facebook, kriz öncesi evrede riski tespit etmek ve azaltmak konusunda yeterli etkinliği gösterememiştir. Paydaşlarının en büyük bölümünü oluşturan kullanıcılarına olumsuz tepki ve olumsuz medya içeriğine karşı çıkmalarını sağlayacak destekleyici bilgi sunmamıştır. Bu da krizi kaçınılmaz kılmıştır.

\section{Krize Tepki Dönemi}

Coombs, kriz meydana geldiğinde kuruluşun "krize tepki evresine" girmiş olduğunu belirtmektedir. Kuruluşun kriz esnasında ne ve nasıl tepki verdiğinin, krizin çıktıları üzerinde önemli etkisi bulunmaktadır. Bu aşamada paydaşlar kriz hakkında doğru ve açık bir biçimde bilgilendirilmeli ve itibarın onarılması için çalışılmalıdır (Coombs, 2012, s.28).

Kriz, 17 Mart 2018'de The Guardian'ın itirafçı olmaya karar veren Cambridge Analytica çalışanı Christopher Wylie söyleşisi ile birlikte sunduğu özel dosya ile patlak vermiştir (The Cambridge Analytica Files, 2018, 17 Mart). Rapora göre Donald Trump'ın seçim kampanyasına ve Brexit'te ayrılıkçıların kampanyasına destek veren Cambridge Analytica, 50 milyondan fazla Facebook kullanıcısının kişisel bilgilerini izinsiz bir biçimde kullanmıştı. Dosya, Cambridge Analytica'dan Beyaz Saray'a uzanan karmaşık ilişki ağını net bir biçimde ortaya çıkarmaktaydı. Dosyada Wylie, Kogan'ın geliştirdiği projeyi Nix ile birlikte aşırı sağcı yayın politikasına sahip Breitbart'ın kurucusu ve Donald Trump'ın kampanya stratejisti Steve Bannon'a nasıl sattıklarını, Bannon'ın nasıl CA yönetim kuruluna girdiğini, Robert Mercer'dan 15 milyon dolarlık mali kaynağı Bannon aracılığıyla nasıl sağladıklarını 
anlatıyordu. Wylie, Steve Bannon'a göre siyasetin bir kültür savaşı olduğunu söylüyor ve ekliyordu:

"Bir savaşı kazanmak için silahlara ihtiyaç vardır. Bu bir kültür savaşı olduğuna göre intiyaç duyulan şey bilgi silahlarıydı. Ve biz onun için bunu inşa edebilirdik. Siyaseti değiştirmek için önce kültürü değiştirmek gerekir. Kültürü değiştirmek içinse önce insanları değiştirmek gerekmektedir. Cambridge Analytica'da yaptığımız buydu" (The Guardian, 2018, 17 Mart).

10 milyonlarca kullanıının Facebook verilerinin toplanması için 1 milyon dolar harcandığını belirten Wylie, Cambridge Analytica'nın varlığının ve kuruluşunun bu kullanıcı verileri sayesinde mümkün olduğunu ifade ediyordu. Bilgi silahı haline dönüşecek kişisel verilerin Cambridge Analytica'nın eline ulaşmasının aracı ise, bilgisi dahilinde veya değil Facebook'tu. Bu da krizin sorumluluğunun Facebook'a ait olduğunu gösteriyordu.

Facebook'un krizi yönetebilmek adına attığı ilk adım, olaya ilişkin dosyanın The Observer ve The Guardian, The New York Times ve Channel 4 News'da yayımlanmasından bir gün önce 16 Mart 2018' de Paul Grewal tarafından Newsroom'da Facebook'un veri toplama ve saklama konusundaki politikalarını ihlal ettikleri gerekçesiyle Cambridge Analytica ve SCL Group'un hesaplarını askıya aldığını duyurmak oldu (Facebook, 2018, 16 Mart). Ancak Facebook, "gök gürültüsünü çalma" 3 konusunda başarıı olamadı. Kriz yönetiminde yapılmaması gereken hatalardan ilkini, Guardian Media Group'a dava mektubu yollayarak yaptı.

Facebook haber ortaklıkları başkanı Campbell Brown, krizin ilerleyen günlerinde bu hamlenin yanlışlığını belirterek, "Eğer ben olsaydım muhtemelen Guardian'ı dava etmekle tehdit etmezdim, akıllıca bir hareket değildi." şeklinde konuştu (Grierson, 2018, 23 Mart).

Skandalın medyada yer bulmasının ardından Facebook, 17 Mart'ta, bir gün önce yayınladığı açıklamaya bir paragraflık güncelleme ekledi: “Veri ihlali olduğuna dair iddialar tamamen yanlış. İnsanlar bilgilerini bilerek paylaştılar, hiçbir sistem sızıntısı, hiçbir parola ya da hassas bilgi çalıntısı gerçekleşmedi." (Facebook, 2018, 17 Mart) Facebook'un en geniş paydaş kitlesi olan kullanıcıları tarafından değerlendirildiğinde, bunun son derece yetersiz, empatiden ve krizi kontrol etmekten çok uzak bir açıklama olduğu söylenebilmektedir. 19 Mart'ta yine Newsroom üzerinden, Cambridge Analytica üzerinde denetim yapmak için dijital danışmanlık firması Stroz Friedberg'ün Facebook tarafından yetkilendirildiği açıklanmıştır (Facebook, 2018, 19 Mart).

Lukaszewki kriz yönetimini tanımlarken "sağduyunun şimşek hızında uygulanması" ifadesi ile krize çok hızlı bir şekilde tepki verilmesi ihtiyacını vurgu-

3 Deyim, "to steal someone's thunder": başkası yapmadan önce onun yapacaklarını yaparak elde edeceği başarı ve alacağı övgünün önüne geçmeyi ifade etmek için kullanımaktadır. 
lamaktadır (Lukaszewski, 2013, s.23). Sosyal medya devi olan Facebook, sosyal medyanın hız ve etkileşimli olma özelliklerini kullanamamış; krize hızla tepki verme konusunda başarısız olmuştur. Şirket borsada 50 milyar dolardan fazla değer kaybederken (NASDAO 2018, 20 Mart), 50 milyondan fazla kullanıcının verilerinin suistimali konusunda ne CEO Mark Zuckerberg ne de COO Sheryl Sandberg, dört gün boyunca hiçbir açıklamada bulunmamıştır. Facebook'un ilk çalışanlarından ve Zuckerberg'in eski konuşma yazarı olan Kate Losse, Cambridge Analytica tartışmasının önceki Facebook gizlilik skandallarından farklı olduğunu ve şirketin çalışma modelinin özünde kolayca düzeltilemeyecek bir sorun olduğunu ifade etmiştir: "Facebook verilerinin üçüncü taraf geliştirici uygulamalar aracılığıyla dış kaynaklara açıklanması" (Tüfekçi, 21.03.2018).

Dört günlük sessizliğin ardından, krizin beşinci gününde Mark Zuckerberg bir Facebook gönderisi yayınlamıştır (Zuckerberg, 2018, 21 Mart). Metinde, "Verilerinizi korumaya yönelik sorumluluğumuz var, eğer bunu yapamıyorsak size hizmet etmeyi hak etmiyoruz. Tam olarak ne olduğunu anlamak ve bunun bir daha olmayacağından emin olmak için çalışıyorum." ifadeleri yer alıyordu. Zuckerberg, aynı gün CNN yayınında olayı "büyük bir güven ihlali" olarak nitelendirmiş ve "Bunun için gerçekten üzgünüm. Tekrar yaşanmaması için gerekli önlemleri alacağız." şeklinde konuşmuştur. Bu noktada Facebook'un SCCT Kriz Tepki Stratejileri'nden "af dileme" ye başvurduğu görülmektedir. Ancak geç gelen bu özrün içtenliği ve bugüne kadar yaşadığı en büyük kriz bu olsa da, daha önce de veri güvenliği ile ilgili defalarca sıkıntı yaşayan şirketin inanılırlığı tartışıır durumdadır. "Pişmanlık" belirtirken empati kurarak, daha içten; ilgi, iyileştirme ve düzeltme içeren bir stratejiyle ilerlemek gerekmektedir. Facebook 25 Mart 2018 Pazar günü çeşitli ABD ve Ingiltere gazetelerinde Zuckerberg imzalı tam sayfa bir özür ilanı yayınlamıştır.

Görsel 1. Facebook Özür Illanı

\section{We have a responsibility to protect your information. If we can't, we don't deserve it.}

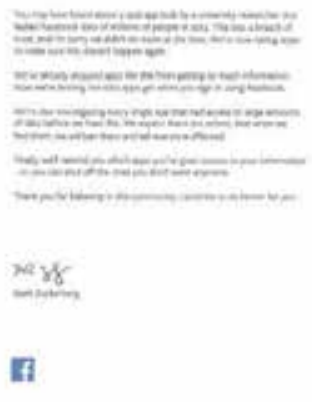


Retorik arenadaki bir diğer ses ise Cambridge Analytica'ydı. Skandalın medya yansımasının ve CEO Alexander Nix'in Channel 4 News'ta yayınlanan gizli çekim görüntülerinin ardından (görüntülerde Nix politik kampanyaları nasıl yürüttüklerinden, verileri nasıl işlediklerinden, Trump'ın kampanyasının nasıl yönetildiğinden, yaptıkları yasal ihlallerden; rüşvetten, hayat kadınlarının kullanımına, etik dışı birçok yöntemi nasıl kullandıklarına dair pek çok bilgi veriyordu) Nix, verilerin saptırıldığını, şirketin kasten tuzağa düşürüldüğünü söylemiştir.

20 Mart'ta açıklama yayınlayan Cambridge Analytica yönetim kurulu, Nix'in ifadelerinin firmanın değerlerini ve operasyonlarını yansıtmadığını ve görevinin askıya alındığını duyurmuştur (Cambridge Analytica, 2018). Yorumları ve iddiaları incelemek için bağımsız bir soruşturma başlattıklarını belirten şirkette, Nix'in yerini Alexander Tayler almıştır. Kriz boyunca düzenli olarak basın sayfasını güncelleyen Cambridge Analytica 9 Nisan'da "Varsayımların değil gerçeklerin vakti" başlıklı bir açıklama yayımlamıştır (Cambridge Analytica, 2018). Açıklamada yüzlerce veri şirketinin Facebook verilerini benzer şekilde kullandığını belirten Cambridge Analytica, uygunsuz ve yasadışı bir biçimde herhangi bir veri toplamadığını ve başkalarıyla paylaşmadığını vurgulamaktadır. Açıklamada, Facebook'un hiçbir verisini çalmadıkları, Facebook'un Global Science Research'e sağladığı verileri anlaşma dahilinde aldıklarını, hiç kimsenin bilgisinin rızası olmaksızın alınmadığı ifadelerine yer verilmektedir. Ayrıca Guardian'a itirafçı olan Wylie'nin iddia ettiği gibi CA'nın kurucularından olmadığı, şirketin yan kuruluşunda yalnızca 7 ay süreyle çalışmış olduğu, bu yüzden şirketin işleyişi hakkında yeterince bilgiye sahip olamayacağı bildirilmiştir. CA'nın Brexit referandumuna yönelik herhangi bir etkide bulunmadığı, şirketin politik olarak nötr bir ideolojide olduğu ifade edilmektedir.. CA ayrıca "cambridgefacts.com" adlı bir web sitesi kurarak sürece ilişkin kronolojik bilgi sağlamıştır. Bu noktada Cambridge Analytica'nın inkar stratejisi izlediği açıktır. CA herhangi bir sorumluluk ve hata kabul etmemekte, var olan hatanın kuruluş ile ilişkisi olmadığını belirtmektedir.

Kullanıcıların Facebook verilerinin toplanmasını sağlayan “This Is Your Digital Life" uygulamasını geliştiren Aleksandr Kogan ise 21 Mart'ta BBC Radio 4'un Today programında; "Bence, hem Facebook hem de Cambridge Analytica tarafından "günah keçisi" olarak kullanılıyorum. Açıkçası normal olan bir şey yaptığımızı düşündük, uygun şekilde hareket ettiğimizi düşündük. CA her şeyi yasalara uygun yaptığımızdan emin olmamızı sağladı. Yaptığım en büyük hata yeterince soru sormamaktı." şeklinde konuşmuştur (Weaver, 21.03.2018). Kogan'ın “Yaptığımızın doğru olduğunu düşünüyorduk." söylemi göz önünde bulundurulduğunda "iyi niyet" ifade ederek açıkça IRT kriz tepki stratejilerinden "sorumluluktan kaçma"ya başvurduğu görülmektedir. Retorik arenanın makro düzeyde gözden geçirilmesi sonucu, siyasi aktörleri de Facebook - Cambridge Analytica veri ihlali skandalının iletişim sürecinde yer alan aktörler arasında sayabiliriz. ABD Kongresi veri skandalıyla birlikte Zuckerberg'i olaylarla ilgili ifade vermeye çağırmıştır. Senatör Durbin, Zuckerberg'e bir gece önce kaldığı otelin adını ve bir hafta önce kimlere mesaj attığı bilgisini onlarla paylaşıp paylaşmayacağını sormuş, Zucker- 
berg bu soruyu "Hayır" şeklinde yanıtlamıştır. Bunun üzerine Senatör Durbin "Sanırım her şey bundan ibaret, gizlilik hakkınız." şeklinde konuşmuştur. Krizi yaratan temel faktör de buydu. Zuckerberg kendi özel bilgileri ve gizlilik hakkı konusunda oldukça dikkatliydi; ancak aynı dikkati yarattığı platforma katılan kullanıcıların verileri için göstermekten uzaktı.

Olayın duyulmasını sağlayan muhbir Christopher Wylie de 13 Mayıs'ta ABD Senatosu Yargı Komitesi önünde ifade vermiştir. ABD Federal Ticaret Komisyonu da, Facebook'un gizlilik uygulamalarına ilişkin kaygıları arttıran son basın raporlarını çok ciddiye aldığını belirterek bu uygulamalara ilişkin soruşturma başlattığına dair bir açıklama yayımlamıştır (Federal Trade Comission, 2018, 26 Mart). Avrupa Parlamentosu Zuckerberg'i ifade için çağırmış, parlamento başkanı Antonio Tajani, Zuckerberg ile kapalı bir görüşme yapacaklarını duyurmuştur (Rankin, $16 \mathrm{Ma}$ yıs 2018). Fransa Cumhurbaşkanı Emmanuel Macron da Zuckerberg ile olaya ilişkin görüşme yapacağını bildirmiştir. Hindistan ve Brezilya hükümetleri Cambridge Analytica'dan bölgesel politik kampanyalarda verileri nasıl kullandıklarına yönelik rapor sağlamalarını istemiştir. Ingiltere Parlamentosu Komisyonu da Facebook'u ifade vermeye çağırmış, Facebook ifadeye CTO'su Mike Schroepher'ı göndemiş ancak komisyon Schroepher'ın cevaplarından tatmin olmadığını belirterek ifade vermesi için Zuckerberg'i davet etmiştir. Zuckerberg'in komisyona katılım sağlamaması halinde ülkeye bir sonraki girişinde ifade için zorla getirileceği belirtimiştir (Digital, Culture, Media and Sports Committee, 2018, 1 Mayıs). Mevcut Avrupa Birliği veri koruma yasasına uyduğunu açıklayan Facebook, 25 Mayıs 2018'de yürürlüğe girecek Genel Veri Koruma Yönetmeliği'ne (GPDR) de uyacağını belirtmiştir (Facebook, 2018).

Retoriksel arenanın içerisinde gönderilen mesajları alırken bir yandan da mesaj üreten aktörlerden biri de Facebook kullanıcılarıydı. Veri ihlalinin medyaya yansımasının ardından milyonlarca kullanıcı, "\#DeleteFacebook" hashtagini kullanarak mesajlarını paylaşmış ve Facebook'a karşı bir hesap silme hareketi başlatılmıştır. Facebook tarafından satın alınan WhatsApp'ın ortak kurucusu Brian Acton, "Facebook'u silme zamanı" paylaşımında bulunmuştur. Elon Musk, var olduğundan haberi olmadığını ifade ettiği SpaceX ve Tesla Facebook sayfalarını sileceğini bildirmiştir. Edward Snowden olaya ilişkin, "Özel yaşamların ayrıntılı kayıtlarını toplayarak ve satarak para kazanan kuruluşlar açıkça "gözetim şirketleri" olarak tanımlanıyorlardı. Bu kuruluşların "sosyal medya" olarak yeniden markalanması, Savaş Bakanlığı'nın Savunma Bakanlığı adını almasından bu yana en başarılı aldatmaca." satırlarını paylaşmıştır. (Snowden, 2018, 17 Mart). "\#DeleteFacebook" hareketine ilişkin The New York Times'a konuşan Zuckerberg, "anlamlı bir sayıda" hesap silme eylemi görmediklerini ancak yine de bu hareketin şirket için iyi olmadığını ve ortada olan güven sorununu çözmek için sorumlulukları olduğunu söylemiştir (Murdock, 5 Nisan 2018). 


\section{Kriz Sonrası Dönem ve Kriz Yönetiminin Değerlendirilmesi}

Bu aşama operasyonların normale döndükten sonraki eylemleri ve paydaşlara yönelik tamamlayıcı bilgilerin sağlanması, soruşturmalar ile ilgili iş birliği ve krizden ders alma aşamasıdır. Normal durumun yeniden sağlanması kriz yönetim sürecinin temel hedefidir. Ayrıca bu aşamada itibarın tamir edilmesi süreci de devam etmektedir (Coombs, 2012, s.45).

Olaya ilişkin "Kriz çözümlendi" yargısına varmak henüz mümkün değildir. Bu yüzden Facebook - Cambridge Analytica veri skandalına ilişkin retorik arena hala açık durumdadır. Normale dönüşün sağlanıp sağlanmadığına ilişkin bir değerlendirmede bulunacak olursak: 16 Mart'ta 185,09 USD olan Facebook hisse değeri, 28 Mart'a gelindiğinde 153,03 USD'e gerilemiş bu düşüş Facebook'a 80 milyar dolarlık pazar değeri kaybı yaşatmıştır (La Monica, 2018, 27 Mart). 16 Mayıs'a gelindiğinde krizin patlak vermesinden iki ay sonra hisse değerinin 183,03 USD'e yükseldiği, bu anlamda bir normale dönüş sağlandığı görülmektedir. Ancak Facebook ile ilgili yasal soruşturmalar devam etmektedir. Zuckerberg Mayıs sonunda Avrupa Parlamentosu 'nda ifade vermiştir, aynı tarihte Ingiltere Parlamentosu Komisyonu da Zuckerberg'in ifadesini beklemektedir. Facebook güvenlik ve gizlilik uygulamalarına ilişkin yeni önlemler geliştirmekte, sitenin nasıl işlediğini ve reklamları kullanıcılara daha açık ve şeffaf biçimde aktaracağını ve kullanıcılar için "Geçmişi Temizle"me imkanı getireceklerini duyurmuştur (Facebook, 2018, 1 Mayıs). Newsroom üzerinden sitedeki güvenlik açıklarının tespit edilmesi için çağrıda bulunulmuş, bu açıkları bulup bildirenlerin $500 \$ \& 40.000 \$$ arasında bir para ile ödüllendirileceği ilan edilmiştir. Federal Ticaret Komisyonu'nun Facebook üzerinde başlattığı soruşturmanın nasıl sonuçlanacağı ve bireysel kullanıcılar tarafından açılabilecek davalar ile Facebook'un nasıl bir para cezası ile karşı karşıya kalabileceği henüz bilinmemektedir.

Krizin sorumluluğunun atfedildiği birinci taraf olan Facebook, normale dönebilmek, itibarını onarabilmek ve paydaşlarının güvenini yeniden kazanabilmek için gerekli düzenlemeleri yapmayı vadetmiştir. Ancak bunu ne kadar doğru yapabildiği ve yapabileceği şüpheli haldedir. Zira "sahte haber" konusunda da kriz yaşayan Facebook'un "kaliteli haberler"in öne çıkması için yaptığı algoritma değişikliği beklenenin tersi yönünde etki gösterdi ve CNN, NBC, New York Times haberlerini sıralamada geriye attı (Ingram, 7 Mayıs 2018).

Krizin sorumluluğunun atfedildiği bir diğer taraf Cambridge Analytica ise, krize tepki evresinde kendine yöneltilen iddiaların asılsız olduğunu söylemiş, CA'nın avukatı Julian Malins "iddiaların gerçekler tarafından doğrulanamadığını" belirtmiştir. Bu aşamada genel olarak "var olmama" ve "mesafe" stratejileri uygulayan Cambridge Analytica'nın normale dönemeyip, krizi aşamadığını 2 Mayıs'ta yaptığı açıklamada, üst kuruluşu SCL Group ile birlikte tüm faaliyetlerini durdurduğunu belirtmesi ve iflas sürecini başlattığını duyurmasıyla görülmektedir (Cambridge Analytica, 2018). 
Facebook, veri skandalında, habersizce verileri alınan kullanıcı sayısının 87 milyona varabileceğini açıklamış ve kullanıcıların verilerinin üçüncü parti uygulamalarla paylaşıı paylaşımadığını görmesi için bir eklenti geliştirmiş̧tir (Cuthbertson, 9 Nisan 2018). Facebook'un proaktif bir kriz yönetimi yerine reaktif bir yönetim anlayışı benimsemesi, krizin yönetilmesini güç bir hale getirmiştir. Facebook krizi yönetmeye çalışırken, doğru hamlelerde bulunsa da, kriz yönetimindeki en önemli faktörlerden "hız" ve "şeffaflık" konularında başarısız olmuştur. CEO Mark Zuckerberg özür dileyerek kurumsal savuncaya başvurmuştur. Kellerman'ın samimi bir özür için sıraladığı kıstaslar (Kellerman, 2006, s.76) ile Zuckerberg'in özrü kıyaslandığında; sorumluluğun kabul edildiğini ve pişmanlık ifade edildiğini görülmektedir.

Ancak diğer üç kıstas, kusurun ifade edilmesi (Facebook, verilerin herhangi bir güvenlik ihlaliyle alınmadığını belirtti, Facebook'a göre "kullanıcılar verileri bilerek paylaşmıştı".), kusurun tekrarlanmayacağının güvencesini vermek (Facebook, ne olduğunu anlamaya çalıştıklarını ve bunun bir daha yaşanmaması için uğraşacaklarını belirtti ancak daha önce de hatalar yaptıklarını ve yine yapacaklarını ekledi, bu noktada Facebook'un "güven uyandırdığını" söylemek güç.) ve son olarak doğru zamanlama ile çabuk hareket etmek (Facebook harekete geçmekte çok yavaştı, Zuckerberg'in özrü krizin 5. gününde geldi.) Facebook'un özrüyle örtüşmemektedir. Ayrıca Facebook, Aleksandr Kogan'ın uygulamasına akademik bir amaç için izin verdiklerini, Kogan'ın Facebook'u bu konuda kandırdığını ve Cambridge Analytica'dan verileri silmelerini istediklerini, CA'nın da verileri sildiğini söyleyerek Facebook'u kandırdığını ifade etmiştir. "Kandıııdık" diyen Facebook kriz iletişimi süresince kriz tepki stratejilerinden4; basitçe inkar, suçu başkasına atma, sorumluluktan kaçma, geçersiz kılma, kaza, ayırt etme, düzeltici eylemde bulunma ve af dilemeye başvurmuştur.

\section{Tartışma ve Sonuç}

Beklenmedik anlarda ortaya çıkan krizler, kuruluşların varlıklarına ve hedef kitleleriyle ilişkilerine yönelik tehdit oluşturan, hızla cevap verilmesi gereken olumsuz olaylardır. Kriz ile karşı karşıya kalan kuruluşlar, kriz tepki stratejilerini uygulayarak krizin üstesinden gelmek ve kısa sürede yeniden normalleşmeyi sağlamak adına çalışırlar. Bu sebeple krizi en az zararla atlatmak ve varlıklarını sürdürmek isteyen kuruluşların hedef kitleleri, paydaşları ve kriz sürecine dahil olan diğer aktörlerle kuracakları iletişim oldukça önemlidir. İtibarını ve paydaşlarıyla iliş̧kilerini korumak isteyen kurumların kriz iletişimi sürecinde başvuracakları stratejilerin etkili ve doğru bir biçimde uygulanması gerekmektedir. Kuruluşların kriz yönetimi sürecinde belirledikleri strateji ve uyguladıkları taktiklerin kuramsal arka planı, kriz iletişimi kuramları incelendiğinde idrak edilebilir.

Coombs (2010, s.338) tarafından "kuruluşu korumak için tasarlanan her tür kriz tepki stratejisi" olarak ele alınan kurumsal savunca, kuruluşun kendini

4 İlgili tablo için bkz. (Çınarlı, 2016, s.50). 
savunma biçimi ve paydaşlar üzerindeki etkinin yönetilmesiyle ilgilidir. Kurumsal savunca üzerine inşa edilen İmajın Yeniden İnşası Kuramı (IRT), itibarı savunmak için iletişimi kullanır ve söylemlerin içeriğine odaklanırken IRT'yi daha ileri taşıyan stratejik bir yaklaşım olarak Durumsal Kriz Illetişimi Kuramı, kriz iletişiminin hem biçimine hem de içeriğine yoğunlaşmaktadır. Kriz iletişimi sürecinin yalnızca gönderici ve alıcı ile sınırlı olmadığını düşünen Frandsen ve Johansen'e göre kurumsal savunca ve imajın yeniden inşası yaklaşımı yalnızca mesajın göndericisini, durumsal kriz iletişimi yaklaşımı ise yalnızca mesajın alıcısını ön planda tutan stratejilerdir (Frandsen ve Johansen, 2017, s.147). Frandsen ve Johansen (2012), geliştirdikleri Retoriksel Arena Kuramı ile kriz iletişimi sürecinin kurum dışı aktörleri de barındıran, çok sesli bir süreç olduğunu öne sürüp; kriz öncesi ya da sırasında açılan metaforik arenada çarpışan seslerin kriz sürecine etkisi üzerine odaklanmaktadır.

Bu noktada, çalışma kapsamında bir vaka analizi olarak değerlendirilen Facebook \& Cambridge Analytica veri krizini incelemek üzere retoriksel arena kuramının teorik çerçeve olarak seçilmesinin sebepleri; krizin sorumluluğunun birden fazla kişi ve kuruluşa yüklenebilmesi, kriz iletişimi ve yönetimi sürecinin farklı aktörler tarafından gönderilen mesajlarla çok sesli bir ortamda şekillenmesi ve veri skandalını etkileşimsel bir çerçevede değerlendirerek, krizlerin çok sesli yapısını yansıtabilme amacıdır. Facebook \& Cambridge Analytica veri krizinde çoklu mesaj göndericileri ve alıcılarının arasındaki ilişkiler ve sosyal etkileşimlerin krizin bağlamını biçimlendirmesi, krize tek yönlü yaklaşan diğer kuramlar yerine, çok sesli bir değerlendirme sunan Frandsen ve Johansen'in yaklaşımının tercih edilmesinin gerekliliğini kanıtlamaktadır. Kriz iletişimi çalışmalarının büyük bir çoğunluğunda krizlerin çok sesli yapısının göz ardı edilmesi ve literatürde retoriksel arena kuramıyla değerlendirilen kriz iletişimi çalışmalarına çok az sayıda rastlanması, çalışmanın önemini ve alana katkısını ortaya koymaktadır.

Retorik arena makro düzeyde gözden geçirildiğinde; Facebook, Cambridge Analytica ve aynı zamanda ana şirket olarak SCL Group gibi kurumsal aktörlerin yanı sıra; kullanıcı verilerinin alınmasını sağlayan uygulamayı geliştiren akademisyen Aleksandr Kogan, skandalı ortaya çıkaran eski Cambridge Analytica çalışanı Christopher Wylie, siyasi aktörler (ABD, Ingiltere, Brezilya, Hindistan hükümetleri, Fransa Cumhurbaşkanı, İngiliz Parlamentosu Komisyonu, Avrupa Parlamentosu, ABD Senatosu Yargı Komitesi ve Kongresi), Facebook kullanıcıları ve The Observer, The Guardian, The New York Times ve Channel 4 News başta olmak üzere yazılı ve görsel medya kuruluşları krizin iletişim sürecini etkileyen kurum dışı diğer aktörler olarak saptanmıştır. Bu aktörler aynı zamanda mikro modelin mesajın kaynağı ve mesajın alıcıları öğelerini de oluşturmakta ve bir diğer öğe olan kriz iletişimi kapsamında da yer almaktadır. Aralarında birliktelik ya da çatışma bulunan bu aktörlerin krizi farklı açılardan ele alıp yorumlayarak süreci etkilemeleri mikro modelin dört parametresi olan bağlam, medya, tür ve metin aracılığıyla gerçekleşmiştir. Veri krizine yönelik retoriksel arenanın doğası hem kurumsal hem de sosyal bağlamda sekillenmiştir. Mesaj göndericilerinden Facebook, farklı medya- 
ları (kurumsal, yazılı, görsel, elektronik, sosyal) kullanırken, Cambridge Analytica sınırlı medyayı (kurumsal, yazılı) kullanmıştır.

Çalıșma kapsamında, Facebook ve Cambridge Analytica'nın, Coombs'un (2012) "kriz iletişiminin üç evresi" olarak belirlediği kriz öncesi, krize tepki ve kriz sonrası evrelerdeki durumları belirlenmiş; ürettikleri mesajlar ve başvurdukları söylemsel stratejiler ortaya konarak sürecin iletişimsel karmaşıklığı yansıtılmıştır. Mikro modelde kriz tepki stratejilerinin bileşeni olduğu metin ve metinler topluluğunun oluşturduğu tür incelendiğinde Facebook'un başlangıçta var olmama ve mesafe stratejisi izlediği ancak krizin seyri içerisinde af dilemeye başvurduğu; Cambridge Analytica'nın ise süreç boyunca inkar, saldırı ve mesafe stratejisi izlediği görülmüştür. Krizin sorumluluğunun atfedildiği taraflar olan kuruluşlar Facebook ve Cambridge Analytica ve yöneticileri, arenada uyguladıkları stratejilerle çatışan sesleri ikna etmekte başarılı olamamış, bunun sonucunda ceza davaları ve yaptırımlarla karşı karşıya kalmıştır.

Özetle kriz, söz konusu iki kuruluş için de bir dönüm noktası olarak görülmüştür. Başvurdukları farklı kriz tepki stratejileri ve arenada diğer aktörler tarafından üretilen metinlerin iki kuruluş için doğurduğu farklı sonuçlar tespit edilmiştir. Karşılaşılan dönüm noktası Facebook için "dönüşmek" anlamını taşırken, Cambridge Analytica için "yok olup gitmek" anlamına gelmiştir. Düşen hisse değerleri, kullanıcı ve paydaş yorumları, geleneksel ve yeni medyada üretilen mesajların yanı sıra siyasi aktörlerin ve hükümetin de krizin yarattığı karmaşık iletişim ortamına müdahalesinin; kuruluşları kabullenme, özür dileme ve hatalarını düzeltici eylemde bulunma konusunda harekete geçirdiği görülmüştür. Küresel kuruluşların yaşadıkları krizler, yalnızca bu kuruluşlarla sınıllı olmayan, seyri kurum dışı aktörlerce de etkilenebilen, etkisi küresel çapta hissedilen karmaşık ve etkileşimli olaylar olarak değerlendirilmiştir.

Sonuç olarak, kuruluşlar kriz ortamının çok sesliliğini göz ardı etmemeli, kriz öncesinde veya anında açılacak arenada sesine eşlik edecek ve karşıt seslerle müzakere edecek müttefikler edinmelidir. Bu müttefikler, kuruluşların paydaşlarından başkası değildir. Kamu çıkarı ve bireyin mahremiyetini gözeten bir yönetim anlayışı güden kuruluşlar paydaşlarıyla güvene dayalı daha iyi ilişkiler kuracak ve gelecekteki krizlere karşı direnç kazanacaktır.

\section{Kaynakça}

Adams, T. (24 Mart 2018). Facebook's week of shame: The Cambridge Analytica fallout.The Guardian. Erişim 7 Mayıs 2018, https://www.theguardian.com/ technology/2018/mar/24/facebook-week-of-shame-data-breach-observer-revelations-zuckerberg-silence

Barrett, B. (19 Mart 2018). Facebook owes you more than this. Wired. Erişim 7 
Mayıs 2018, https://www.wired.com/story/facebook-privacy-transparency-cambridge-analytica/

Binark, M. (2017). Algoritmaların Yarattığı Yankı Odaları ve Siyasal Katılım Olanağı veya Olanaksızlığı. Varlık Dergisi, (1317), 19-23.

Bucher, T. (2017). The algorithmic imaginary: exploring the ordinary affects of Facebook algorithms. Information, Communication \& Society, 20(1), 30-44.

Bump, P. (20 Mart 2018). A new undercovervideo raises significant questions about Cambridge Analyticaıs elections work. The Washington Post. Erişim 7 Mayıs 2018, https://www.washingtonpost.com/news/politics/wp/2018/03/20/a-new-undercover-video-raises-significant-questions-about-cambridge-analyticas-elections-work/?noredirect=on\&utm_term=.e6a843be25ae

The Cambridge Analytica Files (2018). The Guardian. Erişim 5 Mayıs-10 Ekim 2018, https://www.theguardian.com/news/series/cambridge-analytica-files

Cadwalladr, C. (17 Mart 2018). 'I made Steve Bannon's psychological warfare tool': meet the data war whistleblower. The Guardian. Erişim 5 Mayıs 2018, https://www.theguardian.com/news/2018/mar/17/data-war-whistleblower-christopher-wylie-faceook-nix-bannon-trump

Cadwalladr, C. ve Graham-Harrison, E. (17 Mart 2018). Revealed: 50 million Facebook profiles harvested for Cambridge Analytica in major data breach. The Guardian. Erişim 5 Mayıs 2018, https://www.theguardian.com/news/2018/mar/17/ cambridge-analytica-facebook-influence-us-election

Cambridge Analytica basın duyuruları. Cambridge Analytica. Erişim 5 Mayıs - 10 Ekim 2018, https://ca-commercial.com/news

Chaykowski, K. (21 Mart 2018). Mark Zuckerberg Addresses iBreach Of Trustı In Facebook User Data Crisis. Forbes. Erişim 7 Mayıs 2018, https://www.forbes. com/sites/kathleenchaykowski/2018/03/21/mark-zuckerberg-addresses-breach-of-trust-in-facebook-user-data-crisis/\#52da34c03e36

Coombs, T. W. (2018). Crisis communication. Encyclopedia of public relations, 2.

Coombs, T. W. (2015). Ongoing Crisis Communication: Planning, Managing and Responding (4. baskı). Sage Publications.

Coombs, T. W. (2012). Parameters for crisis communication. Coombs, T. W., ve Holladay, S. J. (Ed.) The Handbook of Crisis Communication içinde (17-53). Ingiltere: Wiley \& Blackwell.

Coombs, T. W. ve Holladay S. J. (2004). Reasoned action in crisis communication: An attribution theory-based approach to crisis management. Millar, D.P. ve Heath, R.L. (Ed.) Responding to Crisis: A Rhetorical Approach to Crisis Communication içinde (95-115). New Jersey: Lawrence Erlbaum.

Coombs, T.W. (2007). The Development of the Situational Crisis Communication Theory. Hansen-Horn, T.L \& Neff (Ed.) Public Relations: From Theory to Practice 
içinde (262-277). NJ: Pearson.

Çınarlı, i. (2009). Belirsizlik Toplumunun Krizi. İstanbul: Beta Yayınları.

Çınarlı, I. (2016). Kriz İletişimi. İstanbul: Beta Yayınları.

Çınarlı, í. (2014). Bir Kriz Iletişimi Yönetimi Vaka Analizi: Kaybolan Malezya Havayolları MH370 Sefer Sayılı Uçağı. Illetişim Kuram ve Araştırma Dergisi, (38), 95-114.

Davies, H.(11 Aralık 2015). Ted Cruz campaign using firm that harvested data on millions of unwitting Facebook users. The Guardian. Erişim 7 Mayıs 2018, https:// www.theguardian.com/us-news/2015/dec/11/senator-ted-cruz-president-campaign-facebook-user-data

Davies, H. (26 Mart 2018). Facebook told me it would act swiftly on data misuse - in 2015. The Guardian. Erişim 5 Mayıs 2018, https://www.theguardian.com/ commentisfree/2018/mar/26/facebook-data-misuse-cambridge-analytica

Der, G. (2017). Kriz İletişiminde Çok Sesli Yaklaşım: Metro Turizm Krizinin Retoriksel Arena Kuramı Bağlamında İncelenmesi.Yüksek lisans tezi. Kadir Has Üniversitesi.

Digital, Culture, Media and Sports Committee. (1 Mayıs 2018). Oral evidence from Facebook. Erişim 17 Mayıs 2018, https://www.parliament.uk/documents/ commons-committees/culture-media-and-sport/180501-Chair-to-Rebecca-Stimson-Facebook-re-oral-evidence-follow-up.pdf

Edwards, J. (6 Nisan 2018). Sheryl Sandberg: Facebook knew about Cambridge Analytica 2 1/2 years ago but didnıt follow up. Business Insider. Erişim 5 MayIs 2018, http://www.businessinsider.com/sheryl-sandberg-facebook-knew-about-cambridge-analytica-2018-4

Facebook duyuruları. Facebook. Erişim 5 Mayıs-10 Ekim 2018, https://newsroom.fb.com/news/2018/

Falkheimer, J., \& Heide, M. (2009). Crisis communication in a new world. Nordicom review, 30(1), 55-66.

Fearn-Banks, K. (2011). Crisis communication: A casebook approach (4. baskı). New York: Routledge.

Federal Trade Comission. (26 Mart 2018). Erişim 5 Mayıs 2018, https://www.ftc. gov/news-events/press-releases/2018/03/statement-acting-director-ftcs-bureau-consumer-protection

Frandsen, F. ve Johansen, W. (2018). Voices in Conflict? The Crisis Communication of Meta Organisations. Management Communication Quarterly, 32(I), 90-120. Sage.

Frandsen, F. ve Johansen, W. (2013). Rhetorical Arena (Crisis Theory). Heath, R. L.(Ed.) Encyclopedia of Public Relations içinde (797-800). ABD: Sage Publica- 
tions.

Frandsen, F. ve Johansen, W. (2010). Crisis communication, complexity, and the cartoon affair: A case study. Coombs, T. W., ve Holladay, S. J. (Ed.) The Handbook of Crisis Communication içinde (425-448). Malden, MA: Wiley-Blackwell.

Frandsen, F., \& Johansen, W. (2017). Organizational crisis communication: A multivocal approach. İngiltere: Sage.

Frenkel, S. \& Rosenberg, M. (18 Mart 2018). Facebook's Role in Data Misuse Sets Off Storms on Two Continents. New York Times. Erişim 5 Mayıs 2018, https://www.nytimes.com/2018/03/18/us/cambridge-analytica-facebook-privacy-data.html

Grunig, J.D. \& Hunt, T. (1984). Managing Public Relations. NY: Holt, Rinehart and Winston.

Glazer, R. (26 Nisan 2018). Lessons In Crisis Management From Facebook And Starbucks. Forbes. Erişim 7 Mayıs 2017, https://www.forbes.com/sites/robertglazer/2018/04/26/lessons-in-crisis-management-from-facebook-and-starbucks/3/\#1f2e107c3e97

Grierson, J. (23 Mart 2018). Facebook says warning to Guardian group "not our wisest" move. The Guardian. Erişim 1 Haziran 2018, https://www.theguardian. com/news/2018/mar/23/facebook-says-warning-to-guardian-group-not-our-wisest-move

Heath, R.L. (Ed.) (2013). Encyclopedia of Public Relations (2. Baskı). Sage.

Hermann, C.F. (1963). Some consequences of crisis which limit the viability of organizations. Administrative Science Quarterly, (8), 61-82.

Kellerman, B. (2006). When should a leader apologize-and when not?. Harvard Business Review, (4), 73-81.

Kim, M. (2016). Facebookıs Spiral of Silence and participation: The role of political expression on Facebook and partisan strength in political participation. Cyberpsychology, Behavior \& Social Networking, 19(12), 696-702.

Kosinski, M ve Stillwell, D. (2012). Manifestations of user personality in website choice and behaviour on online social networks. Erişim 8 Mayıs 2018, https://www.microsoft.com/en-us/research/wp-content/uploads/2016/11/kbksg_ ML2013.pdf

Lerbinger, O. (2012). The Crisis Manager: Facing Disasters, Conflicts and Failures. NY: Routledge.

Lukaszewski, J. E. (2013). On Crisis Communication: What Your CEO Needs to Know About Reputation Risk and Crisis Management. ABD: Rothstein Publishing.

Madrigal, A.C. (19 Aralık 2018). Facebook didn't sell your date: it gave it away. 
The Atlantic. Erişim 21 Aralık 2018, https://www.theatlantic.com/technology/archive/2018/12/facebooks-failures-and-also-its-problems-leaking-data/578599/

NASDAQ Facebook. (16-20 Mart 2018). Erişim 10 Mayıs 2018, https://www.nasdaq.com/symbol/fb

Omnicore Agency. (2018). Erişim 15 Mayıs 2018, https://www.omnicoreagency. com/facebook-statistics

Porter, J. (29 Kasım 2018). Facebook might not sell user data, but internal documents suggest it was certainly considered. The Verge. Erişim 1 Aralık 2018, https://www.theverge.com/2018/11/29/18117582/facebook-six4three-internal-documents-emails-selling-user-data

Pressman, A. \& Nusca, A. (5 Nisan 2018). How Zuckerberg Acts in Crisis. Fortune.

Erişim 5 Mayıs 2018, http://fortune.com/2018/04/05/data-sheet-zuckerberg-in-crisis-facebook/

Reid, J. L. (2000). Crisis management: Planning and media relations for the design and construction industry. John Wiley \& Sons.

Reynolds, B. \& Seeger, M.W. (2005). Crisis and Emergency Risk Communication as an Integrative Model. Journal of Health Communication, 10:1, 43-55.

Rosenberg, M. (17 Mart 2018). How Trump Consultants Exploited the Facebook Data of Millions. New York Times.

Roux Dufort, C. (2007). Is crisis management (only) a management of exceptions?. Journal of contingencies and crisis management, 15(2), 105-114.

Erişim 8 Mayıs 2018, https://www.nytimes.com/2018/03/17/us/politics/cambridge-analytica-trump-campaign.html

SCL Group. (2018).Erişim 7 Mayıs 2018, https://sclgroup.cc/missionstatement

Seeger, M. (2006). Best Practices in Crisis Communication: An Expert Panel Process. Journal of Applied Communication Research, 34:3, 232-244.

Snowden, E. (17 Mart 2018). Twitter. Erişim 5 Mayıs 2018, https://twitter.com/ snowden/status/975147858096742405

Stone, B. (2010). Sell your friends: how Facebook plans to leverage its 550 million users into the greatest advertising juggernaut since Google. Bloomberg Businessweek, October 3, 6472.

Thompson, N. (21 Mart 2018). Mark Zuckerberg Talks To Wired About Facebook's Privacy Problem. Wired. Erişim 5 Mayıs 2018, https://www.wired.com/ story/mark-zuckerberg-talks-to-wired-about-facebooks-privacy-problem/

TDK. (2018). Güncel Türkçe Sözlük. Erişim 1 Mayıs 2018, https://sozluk.gov.tr/?kelime $=$ kriz $\% 20 y$ 
Tüfekçi, Z. (2017). We are building a dystopia just to make people click on ads.

Erişim Mayıs 2018,https://www.ted.com/talks/zeynep_tufekci_we_re_building_a_dystopia_just_to_make_people_click_on_ads

Tüfekçi, Z. (21 Mart 2018). Missing From Facebook's Crisis: Mark Zuckerberg. New York Times. Erişim 8 Mayıs 2018, https://www.nytimes.com/2018/03/21/ technology/mark-zuckerberg-facebook.html

Tüfekçi, Z. (19 Mart 2018). Facebook's Surveillance Machine. New York Times. Erişim 8 Mayıs 2018, https://www.nytimes.com/2018/03/19/opinion/facebook-cambridge-analytica.html

Ulmer, R. R., Sellnow, T. L., ve Seeger, M. W. (2011). Effective Crisis Communication: Moving From Crisis to Opportunity (2. Baskı). ABD: Sage Publications.

Wells, J.R. ve Winkler, C.A. (2017). Facebook Fake News in the Post-Truth WorId. Harvard Business School Case Collection.

Wong, J.C. (26 Mart 2018). Facebookıs privacy practices are under investigation, FTC confirms. The Guardian. Erişim 8 Mayıs 2018, https://www.theguardian. com/technology/2018/mar/26/facebook-data-privacy-cambridge-analytica-investigation-ftc-latest

Zoldan, A. (2018). 3 Important Lessons From Facebookıs Deepening PR Crisis. Erişim 10 Ekim 2018, https://www.inc.com/ari-zoldan/what-every-business-can-learn-about-crisis-management-from-facebooks-cambridge-analytica-moment.html

Zuckerberg, M. (21 Mart 2018). Facebook. Erişim 10 Mayıs-10 Ekim 2018, https://www.facebook.com/zuck/posts/10104712037900071

Zuckerberg, M. (2018). Facebook, Social Media Privacy, and the Use and Abuse of Data. Erişim 5 Ekim 2018, https://www.judiciary.senate.gov/meetings/facebook-social-media-privacy-and-the-use-and-abuse-of-data 